\title{
MAKNA YANG TIMBUL DARI KESADARAN MEMBAYAR PAJAK RESTORAN
}

\author{
Alfian Suradiansyah', ${ }^{1}$ Ni Putu Eka Widiastuti ${ }^{2}$, Alfida Aziz $^{3}$ \\ ${ }^{1,2,3}$ Fakultas Ekonomi dan Bisnis Universitas Pembangunan Nasional Veteran Jakarta \\ Email : alfiansuradiansyah@gmail.com
}

Diterima 26 April 2019, Disetujui 20 Juli 2019

\begin{abstract}
Abstrak
Penelitian ini bertujuan untuk memperoleh pemahaman tentang makna pajak restoran pada wajib pajak restoran di Kota Tangerang Selatan. Metode yang digunakan dalam penelitian ini adalah metode kualitatif dengan paradigma intepretif dan pendekatan fenomenologi. Hasil penelitian mengungkapkan bahwa informan telah memahami tentang kewajiban mereka untuk membayar pajak restoran kepada pemerintah daerah. Mereka memahami bahwa perpajakan restoran adalah kewajiban sebagai warga negara yang mendirikan bisnis restoran di daerah terhadap pemerintah daerah yang dapat digunakan sebagai sumber pendapatan daerah untuk membiayai kebutuhan pemerintah daerah. Arti pajak restoran tidak dapat dipisahkan dari latar belakang kehidupan, karakter, budaya dan filosofi mereka. Informan menafsirkan pajak restoran sebagai bentuk timbal balik kepada pemerintah daerah, kedamaian bisnis, berkontribusi pada kawasan dan membentuk rasa tanggung jawab sosial.
\end{abstract}

Kata Kunci : Arti Pajak Restoran, Perspektif Wajib Pajak Restoran.

\section{Abstract}

This research aims to gain an understanding of the meaning of restaurant tax on restaurant taxpayers in South Tangerang City. The method used in this research is a qualitative method with intepretive paradigm and phenomenology approach. The results of the research revealed that the informant had understood about their obligation to pay restaurant taxes to the local government. They understand that restaurant taxation is an obligation as citizens who set up a restaurant business in an area against the regional government which can be used as a source of regional revenue to finance the needs of local governments. The meaning of restaurant tax cannot be separated from their life background, character, culture and philosophy. Informants interpret restaurant taxes as a form of reciprocity to local governments, peace of business, contribute to the region and forming a sense of social responsibility.

Keywords: The Meaning of Restaurant Tax, Restaurant Taxpayer Perspective. 


\section{PENDAHULUAN}

Peraturan Daerah (Perda) Kota Tangsel Nomor 7 Tahun 2010 sebagaimana telah diubah menjadi Perda Nomor 3 Tahun 2017 tentang Pajak Daerah, memberikan kewenangan bagi pemerintah Kota Tangsel untuk menggali potensi sumber-sumber pendapatan, salah satunya dari sektor pajak restoran. Salah satu jenis pajak di daerah tingkat II (Kabupaten/Kota) yaitu Pajak Restoran. Potensi pajak restoran memiliki peluang yang cukup besar. Seiring berjalannya waktu dan banyak bermunculan usaha di bidang makanan atau minuman yang berpotensi dapat menjadi target dari pajak restoran. Dengan kata lain, hal tesebut dapat berdampak pada penerimaan pajak daerah Kota Tangerang Selatan. Berikut disajikan target dan realisasi Pajak Daerah dan Pajak Restoran Kota Tangerang Selatan dalam Tabel 1.
Dapat dilihat realisasi penerimaan pajak restoran dapat melebihi target yang telah ditentukan Pemerintah Kota Tangerang Selatan, dengan persentasi antara realisasi dibagi dengan target lalu dikalikan 100\% dapat diketahui hasil untuk setiap tahunnya mengalami beberapa penurunan, yaitu untuk tahun 2013 sebesar $113.94 \%$ lalu turun menjadi 104.15\% pada tahun 2014, untuk tahun 2013 menjadi yang lebih tinggi presentasinya disebabkan jumlah target ditahun tersebut masih sedikit dibandingkan tahun-tahun berikutnya. Tahun 2015 naik menjadi 108.98\% dan untuk tahun 2016 sampai 2017 turun secara berturut-turut yaitu 106.03\% dan 103.09\%. Terjadinya penurunan tersebut diakibatkan jumlah realiasi pajak restoran yang mendekati jumlah target penerimaan sehingga presentasi yang dihasilkan menjadi lebih kecil.

Tabel 1. Target dan Realisasi Pajak Restoran Kota Tangerang Selatan

\begin{tabular}{lccc}
\multicolumn{4}{c}{ Tahun 2013-2017 } \\
\hline Tahun & Target (Rp) & Realisasi (Rp) & Persentasi (\%) \\
\hline 2013 & $85,000,000,000.00$ & $96,850,835,064.00$ & $113.94 \%$ \\
\hline 2014 & $124,000,000,000.00$ & $129,150,247,174.00$ & $104.15 \%$ \\
\hline 2015 & $141,300,000,000.00$ & $153,989,342,382.00$ & $108.98 \%$ \\
\hline 2016 & $172,000,000,000.00$ & $182,373,767,356.00$ & $106.03 \%$ \\
\hline 2017 & $212,069,000,000.00$ & $218,624,260,439.00$ & $103.09 \%$ \\
\hline
\end{tabular}

Sumber: Badan Pendapatan Daerah Kota Tangerang Selatan Tahun 2013-2017

Informan dari Bapenda Tangsel, Bapak Puguh memberikan pernyataan mengenai data restoran terkait adanya penurunan presentasi sebagai berikut: “Ohh, tapi angka pendapatannya meningkat, artinya kepatuhan wajib pajak nya bagus dengan penambahan wajib pajak yang tidak banyak tetapi menyumbang PAD besar". Walaupun terjadi penurunan presentasi yang didapatkan dari selisih target dan realisasi pajak restoran, tidak mengakibatkan penurunan penerimaan pajak daerah dari sektor restoran. Setiap tahun jumlah realisasi dari pajak restoran selalu melampaui target, sehingga pajak daerah yang diperoleh dari sektor restoran meningkat setiap tahun. Berdasarkan data tersebut, kesadaran dari para pelaku usaha sebagai wajib pajak restoran yang mempunyai kewajiban untuk membayar pajak restoran memiliki peranan penting dalam meningkatkan penerimaan daerah khususnya dari pajak restoran.

Perda Nomor 7 Tahun 2010 Pasal 20 terkait pajak restoran yang menjelaskan tentang "Setiap Wajib Pajak Restoran sebagaimana dimaksud dalam Pasal 19 harus memiliki perijinan yang terkait dengan usaha restoran dari Walikota atau pejabat lain yang ditunjuk”, setelah revisi menjadi Perda Nomor 3 Tahun 2017 Pasal 20 tersebut telah dihapus. Selanjutnya dengan penghapusan pasal tersebut dapat dipastikan setiap wajib pajak restoran yang belum memiliki perijinan dapat ditarik pajak restoran sebesar $10 \%$ dengan catatan telah mencapai omset yang ditentukan dalam Perda tersebut.

Penelitian Jaya dan Jati (2016) dengan metode kuantitatif untuk mengetahui pengaruh sanksi perpajakan, kualitas pelayanan, dan kewajiban moral pada kepatuhan wajib pajak dalam membayar pajak restoran di Dinas Pendapatan Kota Denpasar. Penelitian tentang Pengaruh Pemahaman Wajib Pajak dan Manfaat Pajak Restoran Terhadap Kemauan Wajib Pajak Membayar Pajak, oleh Wowor (2015). Penelitian tentang Pengaruh Kualitas Pelayanan, Pemeriksaan Pajak, Pengetahuan Perpajakan dan Sanksi Perpajakan pada Kepatuhan Wajib Pajak Restoran, oleh Sucandra (2016) diketahui bahwa pengetahuan perpajakan wajib pajak sudah baik mengenai hak dan kewajibannya.

Penelitian ini mencoba melakukan pengembangan dengan menganalisis perspektif pemilik/pengelola usaha restoran tentang bagaimana 
mereka memaknai pajak restoran yang berada di Kota Tangerang Selatan menggunakan metode kualitatif. Kota Tangerang Selatan memiliki potensi yang besar terhadap perkembangan usaha yang berkaitan dengan pajak restoran serta potensi untuk menambah pendapatan asli daerah melalui pajak restoran. Selain itu, dengan adanya aturan baru terkait pajak restoran, untuk menjadi wajib pajak restoran tidak perlu mendapatkan ijin usaha, sehingga pemerintah/dinas pajak daerah hanya perlu merekomendasikan usaha tersebut untuk bisa dikenakan pajak restoran apabila usaha tersebut memperoleh omset yang telah ditentukan dalam perda tentang pajak restoran tanpa harus memiliki izin usaha.

Hasil yang diharapkan dari penelitian ini adalah untuk mengetahui perspektif pemilik/pengelola restoran tentang pajak restoran di Kota Tangerang Selatan, sehingga dari penjelasan pemilik/pengelola restoran tersebut dapat diketahui makna pajak restoran berdasarkan pengalaman mereka sebagai pelaku usaha restoran.

\section{KAJIAN TEORI}

\section{Makna Pajak}

Saussure (Sarnia, 2015) mengungkapkan pengertian makna sebagai pengertian atau konsep yang dimiliki atau terdapat pada suatu tanda linguistik. Makna juga dapat diartikan sebagai pengertian/ konsep yang dimiliki, atau terdapat pada suatu tanda linguistic. Suparnyo (2012, hlm. 15) menjelaskan bahwa teori-teori yang menjadi dasar pembenar pemungutan pajak oleh negara kepada rakyatnya mendasarkan pada tujuan dari pemungutan pajak, yaitu apakah pemungutan pajak untuk kepentingan pemungut, untuk kepentingan yang dipungut, atau untuk kepentingan kedua-duanya. Apabila kita melihat Pancasila yang merupakan dasar negara Indonesia dan menjadi landasan filosofis semua kegiatan penyelenggaraan negara, maka pemungutan pajak oleh negara kepada rakyatnya tersebut dapat dibenarkan jika kita mengacu pada sila kelima yaitu keadilan sosial bagi seluruh rakyat Indonesia. Sila kelima Pancasila tersebut mengandung makna bahwa kita perlu mengembangkan perbuatanperbuatan yang luhur yang mencerminkan sikap dan suasana kekeluargaan dan kegotong royongan.

Pajak adalah salah satu bentuk perbuatan gotong royong yang tidak perlu disyaratkan, melainkan sudah hidup dan berkembang. dalam masyarakat Indonesia yang hanya perlu dikembangkan dan dilestarikan saja. Gotong royong, termasuk di dalamnya membayar pajak merupakan salah satu pengorbanan setiap anggota masyarakat untuk kepentingan bersama tanpa mendapatkan imbalan. Jadi, pemungutan pajak menurut Pancasila dapat dibenarkan, karena pembayaran pajak akhirnya adalah untuk kita bersama.

\section{Pajak Daerah}

Pajak adalah iuran wajib dari masyarakat kepada negara/pemerintah berdasarkan undang-undang, bersifat memaksa dan terutang oleh yang wajib membayarnya tanpa mendapat balas jasa secara langsung, serta digunakan untuk membiayai pengeluaran negara dalam melaksanakan pemerintahan dan pembangunan (Siahaan, 2016 hlm.7). Hal ini menunjukkan bahwa pajak merupakan pembayaran wajib yg dikenakan berdasarkan peraturan atau undang-undang yang tidak dapat dihindari bagi yang memiliki kewajiban untuk membayarnya, dan bagi yang berkewajiban tapi tidak mau membayar pajak, dapat dilakukan paksaan. Pajak Daerah adalah iuran wajib yang dilakukan oleh orang pribadi atau badan kepada Daerah tanpa imbalan langsung yang seimbang. Pajak Daerah dapat dipaksakan berdasarkan peraturan perundangundangan yang berlaku, dimana hasilnya digunakan untuk membiayai penyelenggaraan pemerintahan daerah dan pembangunan Daerah.

\section{Sistem Pemungutan Pajak Daerah}

Karakteristik setiap jenis pajak daerah tidak sama, penetapan sistem self assessment yang diatur dalam Undang-Undang Ketentuan Umum dan Tata Cara Perpajakan Indonesia tidak dapat diberlakukan untuk semua jenis pajak daerah. Siahaan (2016, hlm.90) menjelaskan pemungutan pajak daerah saat ini menggunakan tiga sistem pemungutan pajak, yaitu: a. Menggunakan perwujudan dari sistem self assessment, yaitu dibayar sendiri oleh wajib pajak. Berkaitan dengan hal tersebut, wajib pajak diberi kepercayaan untuk menghitung, memperhitungkan, membayar, dan melaporkan sendiri pajak yang terutang dengan menggunakan SPTPD (Surat Pemberitahuan Pajak Daerah).

b. Menggunakan perwujudan dari sistem official assessment, yaitu pemungutan pajak ditetapkan oleh kepala daerah. Berkenaan dengan hal tersebut, pengenaan pajak yang dibayar oleh wajib pajak setelah terlebih dahulu ditetapkan oleh kepala daerah atau pejabat yang ditunjuk melalui Surat Ketetapan Pajak Daerah atau dokumen lain yang dipersamakan. 
c. Menggunakan perwujudan dari sistem with holding, yaitu dipungut oleh pemungut pajak. Sistem ini dilakukan pengenaan pajak yang dipungut oleh pemungut pajak pada sumbernya, contohnya Perusahaan Listrik Negara (PLN) sebagai pemungut Pajak Penerangan Jalan atas penggunaan tenaga listrik yang disediakan oleh PLN.

\section{Pemungutan Pajak Daerah}

Undang-Undang Nomor 28 Tahun 2009 memuat beberapa hal penting dalam pemungutan pajak daerah yang harus diketahui oleh wajib pajak, diantaranya sebagai berikut:

a. Pemungutan pajak dilarang diborongkan.

b. Setiap Wajib pajak wajib membayar pajak yang terutang berdasarkan surat ketetapan pajak atau dibayar sendiri oleh Wajib Pajak berdasarkan peraturan perundang- undangan perpajakan.

c. Wajib Pajak yang memenuhi kewajiban perpajakan berdasarkan penetapan Kepala Daerah dibayar dengan menggunakan SKPD atau dokumen lain yang dipersamakan.

d. Dokumen lain yang dipersamakan sebagaimana dimaksud pada tersebut berupa karcis dan nota perhitungan.

e. Wajib Pajak yang memenuhi kewajiban perpajakan sendiri dibayar dengan menggunakan SPTPD, SKPDKB, atau SKPDKBT.

\section{Kriteria Pajak Daerah}

Siahaan (2016, hlm.44-45) menjelaskan pemungutan pajak daerah ditetapkan sesuai dengan peraturan daerah dan memenuhi kriteria-kriteria pajak daerah sebagai berikut:

a. Bersifat pajak dan bukan retribusi. Pajak yang ditetapkan oleh pemerintah daerah harus sesuai dengan pengertian pajak, sebagaimana dimaksud dalam pengertian pajak dalam Undang-Undang Pajak Daerah dan Retribusi Daerah.

b. Objek pajak terletak di wilayah daerah Kabupaten/Kota yang telah ditetapkan aturan pajak sesuai dengan peraturan daerah setempat dan mempunyai mobilitas cukup rendah serta hanya melayani masyarakat di wilayah daerah kabupaten/kota setempat.

c. Objek dan dasar pengenaan pajak tidak bertentangan dengan kepentingan umum. Dengan adanya pajak dimaksudkan untuk kepentingan bersama yang lebih luas antar pemerintah dan masyarakat dengan memperhatikan aspek ketentraman dan kestabilan politik, sosial, ekonomi, budaya, pertahanan, dan keamanan.

d. Objek pajak yang bukan merupakan objek pajak provinsi dan/atau objek pajak pusat. Kriteria ini dimaksudkan agar tidak terjadi tumpang tindih pengenaan terhadap objek yang sama, baik di daerah maupun di pusat, sehingga tidak terjadi pengenaan pajak berganda.

e. Potensinya memadai. Hasil penerimaan pajak harus lebih besar dari biaya pemungutan. Kriteria ini berarti bahwa hasil pajak yang dipungut cukup besar sebagai salah satu sumber pendapatan daerah dan laju pertumbuhannya diperkirakan sejalan dengan laju pertumbuhan ekonomi daerah.

f. Tidak memberikan dampak ekonomi yang negatif. Pajak tidak menganggu alokasi sumber-sumber ekonomi dan tidak merintangi arus sumber daya ekonomi antar daerah maupun kegiatan eksporimpor.

g. Memperhatikan aspek keadilan dan kemampuan masyarakat. Kriteria aspek keadilan berarti objek dan subjek pajak harus jelas sehingga dapat dilakukan pengawasan dalam pemungutan pajaknya, jumlah pembayaran pajak dapat diperkirakan oleh Wajib Pajak bersangkutan dan tarif pajakditetapkan dengan memperhatikan keadaan Wajib pajak. Kriteria kemampuan masyarakat, berarti memperhatikan kemampuan subjek pajak untuk memikul tambahan beban pajak.

h. Menjaga kelestarian lingkungan. Kriteria ini berarti bahwa pajak yang bersifat netral terhadap lingkungan, yakni pengenaan pajak tidak memberikan peluang kepada pemerintah daerah atau pemerintah pusat atau masyarakat luas untuk merusak lingkungan, yang akan menjadi beban bagi pemerintah daerah, pemerintah pusat dan masyarakat.

\section{Pajak Restoran Kota Tangerang Selatan}

Peraturan Daerah (Perda) Nomor 7 Tahun 2010 tentang Pajak daerah, menjelaskan Pajak Restoran adalah pajak atas pelayanan yang disediakan oleh restoran, sedangkan pengetian restoran adalah fasilitas penyedia makanan dan/atau minuman dengan dipungut bayaran, yang mencakup juga rumah makan, kafetaria, kantin, warung, bar, dan sejenisnya termasuk jasa boga/catering. Dengan nama Pajak Restoran, dipungut pajak atas pelayanan yang disediakan oleh Restoran:

a. Obyek Pajak Restoran adalah pelayanan yang disediakan oleh Restoran;

b. Pelayanan yang disediakan Restoran meliputi pelayanan penjualan makanan dan/atau minuman 
yang dikonsumsi oleh pembeli, baik dikonsumsi di tempat pelayanan maupun di tempat lain;

c. Dikecualikan dari ketentuan adalah pelayanan yang disediakan oleh Restoran yang nilai penjualannya tidak melebihi Rp.15.000.000,00 (Lima belas juta rupiah) per-bulan.

Subyek Pajak Restoran adalah orang pribadi atau Badan yang membeli makanan dan/atau minuman dari Restoran. Wajib Pajak Restoran adalah orang pribadi atau Badan yang mengusahakan Restoran. Tarif Pajak Restoran ditetapkan sebesar 10\% (sepuluh persen). Dasar pengenaan Pajak Restoran adalah jumlah pembayaran yang diterima atau yang seharusnya diterima Restoran. Besaran pokok Pajak Restoran yang terutang dihitung dengan cara mengalikan tarif pajak restoran dengan dasar pengenaan pajak. Pengusaha restoran harus menambahkan Pajak Restoran atas pembayaran pelayanan di restoran dengan menggunakan tarif pajak. Dalam hal pengusaha restoran tidak menambahkan Pajak Restoran, maka jumlah pembayaran yang digunakan sebagai dasar pengenaan Pajak Restoran.

\section{METODE}

Penelitian ini menggunakan metode kualitatif paradigma interpretif dengan pendekatan fenomenologi. Moleong (2017, hlm. 6) menjelaskan bahwa penelitian kualitatif adalah penelitian yang bermaksud untuk memahami fenomena tentang apa yang dialami oleh subjek penelitian, misalnya perilaku dari objek yang diamati, persepsi, motivasi, tindakan, dan lain-lain. Secara holistik dan deskriptif metode kualitatif disajikan dalam bentuk kata-kata dan bahasa, pada suatu konteks khusus yang alamiah dan dengan memanfaatkan berbagai metode alamiah. Penelitian ini menggunakan metode penelitian kualitatif untuk dapat memperoleh informasi secara lebih mendalam mengenai perilaku pemilik/pengelola usaha restoran dalam melakukan kewajiban perpajakan khususnya pajak restoran, moralitas pemilik usaha terkait kewajibannya membayar pajak restoran di Kota Tangerang Selatan, sehingga yang menjadi obyek dalam penelitian ini adalah manusia bukan benda. Hal ini yang melatarbelakangi peneliti menggunakan metode kualitatif dalam penelitian ini.

Penelitian dengan paradigma interpretif dilakukan untuk mengembangkan pemahaman serta membantu mengerti dan menginterpretasi apa yang ada dibalik peristiwa, bagaimana manusia meletakkan makna pada peristiwa yang terjadi. Paradigma interpretif peneliti gunakan untuk memahami perilaku informan sebagai wajib pajak restoran berdasarkan pengalamannya membayar pajak restoran kepada pemerintah daerah. Selain itu, peneliti mencoba mengungkap maksud dan tujuan pemilik/pengelola restoran dalam membayar pajak restoran. Anggraini (2017) berpendapat bahwa penggunaan paradigma interpretif bertujuan untuk memahami realitas sosial secara lebih mendalam melalui tingkat pengalaman subjektif. Paradigma ini dapat memberikan suatu deskripsi atas realitas sosial yang ada dan tidak dimaksudkan untuk mencari generaliasi, karena tingkat pemahaman dan perilaku masing-masing subjek adalah berbeda.

Pendekatan Fenomenologi digunakan untuk mencoba menjelaskan atau mengetahui pemahaman dari pengalaman yang didasari oleh kesadaran yang terjadi oleh beberapa individu, dalam hal ini adalah pemilik/pengelola restoran sebagai wajib pajak restoran yang berkewajiban membayar pajak restoran di Kota Tangerang Selatan. Penelitian dengan pendekatan fenomenologi memfokuskan untuk mendeskripsikan pernyataan atau jawaban apa yang sama/umum dari partisipan yang menjadi sumber data saat mereka mengalami suatu fenomena. Penelitian ini berusaha untuk mengungkap makna dari berbagai pernyataan informan sebagai wajib pajak restoran yang mempunyai kewajiban membayar pajak daerah khususnya pajak restoran di Kota Tangerang Selatan. Husserl menjelaskan (Rico, 2010 hlm.82) fenomenologi sebagai studi tentang bagaimana orang mengalami dan menggambarkan sesuatu. Seseorang tersebut hanya mengetahui sesuatu, karena sesuatu itu telah dialaminya. Sehingga hal yang penting untuk diketahui adalah apa yang manusia alami dan bagaimana mereka memaknai serta menafsirkan pengalaman tersebut.

Sumber data dalam penelitian ini dapat dikategorikan ke dalam dua kelompok. Pertama, sumber informan (Human Resources) sebagai sumber primer, yaitu pemilik usaha restoran atau wajib pajak restoran di Kawasan Tangerang Selatan. Informan berikutnya adalah Aparatur Sipil Negara (ASN) yang berada di Bapenda (Badan Pendapatan Daerah) Kota Tangerang Selatan khususnya bagianbagian terkait mengenai pajak daerah. Sumber kedua berasal dari bahan cetak (kepustakaan) atau media elektronik sebagai sumber sekunder. Data sekunder tersebut dapat berupa informasi yang didapat melalui artikel, internet, media cetak, dan elektronik, bukubuku, jurnal penelitian, ataupun aturan perundangundangan tentang Peraturan Daerah tentang pajak khususnya mengenai pajak restoran yang diterapkan didaerah Tangerang Selatan. Penelitian ini dilakukan 
pada tiga informan, yaitu dua informan pemilik atau pengelola restoran yang berada di Kota Tangerang Selatan dan satu informan dari Bapenda Tangsel. Peneliti mengambil lokasi tersebut karena pertimbangan jumlah usaha dibidang restoran yang berada di Tangsel membuat peneliti memfokuskan kepada partisipan yang telah mengalami fenomena terkait menjadi wajib pajak restoran.

Pengumpulan data dalam penelitian ini dimulai dari survey pendahuluan. Pada tahapan ini peneliti menggali informasi-informasi up-to date baik melalui artikel, internet, media cetak, dan elektronik, bukubuku, jurnal penelitian, ataupun aturan perundangundangan tentang Peraturan Daerah tentang pajak khususnya mengenai pajak restoram yang diterapkan didaerah Tangerang Selatan. Penelitian ini menggunakan teknik pengumpulan data, pertama melalui wawancara, wawancara adalah pertemuan diantara dua orang untuk bertukar informasi dan pendapat melalui tanya jawab, sehingga menghasilkan konstruksi makna tentang topik tertentu. Kedua melalui pengumpulan dokumen (tulisan-tulisan), mengumpulkan bahan tertulis seperti berita media, surat menyurat dan laporan-laporan untuk mencari informasi yang diperlukan. Kegiatan pengujian kebenaran data menggunakan teknik triangulasi, yaitu penggunaan dua atau lebih sumber atau informan untuk mendapatkan gambaran yang menyeluruh tentang suatu fenomena yang akan diteliti. Triangulasi yang digunakan dalam penelitian ini adalah triangulasi sumber, yaitu membandingkan atau mengecek ulang ukuran kepercayaan suatu informasi yang diperoleh satu sumber yang berbeda.

Langkah-langkah analisis data yang digunakan dalam penelitian ini mengacu pada pendekatan fenomenologi Creswell yang dikutip oleh Hasbiansyah (2008), yaitu:

a. Tahap awal: Peneliti mendeskripsikan sepenuhnya fenomena yang dialami subjek penelitian. Seluruh rekaman hasil wawancara mendalam dengan subjek penelitian ditranskripsikan ke dalam bahasa tulisan.

b. Tahap Horizonalization: Dari hasil transkripsi, peneliti mengumpulkan pernyataan-pernyataan penting yang relevan dengan topik. Pada tahap ini peneliti menunda penilaian (bracketing/ epoche). Artinya, unsur subjektivitas peneliti tidak mencampuri upaya merinci point-point penting, sebagai data penelitian yang diperoleh dari hasil wawancara.

c, Tahap Cluster of Meaning: Selanjutnya peneliti mengklasifikasikan pernyataan-pernyataan tadi ke dalam tema-tema atau unit-unit makna, serta menyisihkan penyataan yang tumpang tindih atau berulang-ulang. Pada tahap ini, dilakukan deskripsi tekstural, yaitu menuliskan apa yang dialami, yakni deskripsi tentang apa yang dialami individu dan melakukan deskripsi struktural, yaitu menuliskan bagaimana fenomena itu dialami oleh para individu. Peneliti juga mencari segala makna yang mungkin berdasarkan refleksi si peneliti sendiri, berupa opini, penilaian, perasaan, harapan subjek penelitian tentang fenomena yang dialaminya.

d. Tahap deskripsi esensi: peneliti mengonstruksi (membangun) deskripsi menyeluruh mengenai makna dan esensi pengalaman para subjek.

e. Peneliti menyajikan narasi tentang esensi dari pengalaman tersebut dalam laporan hasil penelitian atau pembahasan, sehingga menunjukkan adanya kesatuan makna tunggal dari pengalaman, di mana seluruh pengalaman itu memiliki “struktur” yang penting.

\section{HASIL DAN PEMBAHASAN}

\section{Membayar Pajak Restoran Sebagai Bentuk}

\section{Kewajiban dan Taat Hukum}

Sebagai wajib pajak restoran, pemilik/pengelola sebuah restoran juga seharusnya dapat mengetahui apa itu pajak restoran yang selalu ia bayarkan setiap bulan, sehingga pengetahuan pajak restoran dari wajib pajak dapat menimbulkan dampak positif terkait penerimaan pajak daerah khususnya lewat pajak restoran. Realitas di lapangan menunjukkan bahwa pemilik atau pengelola restoran telah memahami apa itu pajak restoran dan melakukan kewajiban perpajakannya. Seperti yang diungkapkan oleh salah satu informan bahwa "Pajak kita dikenain 10\%, jadi kita nanti kalo dari penghasilan kita langsung bayar pajak ke dia 10\% dari penghasilan”. Pernyataan yang disampaikan oleh informan menggambarkan bahwa ia selama ini sudah menjalankan kewajibannya sebagai wajib pajak restoran untuk membayar pajak kepada pemerintah daerah. Informan lain mengungkapkan restorannya sudah wajib pembayar pajak restoran kepada pemerintah daerah. Informan juga menjelaskan pajak restoran yang dikenakan atas usahanya sebesar $10 \%$, penerimaan dari setiap transaksi sudah dipotong pajak restoran, sehingga penerimaan kotor restoran setiap bulannya sudah dipotong pajak restoran sebesar 10\% dan dibayarkan kepada pihak pajak daerah, seperti kutipan berikut ini, "Kalo pajak itu kan udah wajib dari pemerintah untuk warung up normal ini dikenakan 10\% jadi setiap bulannya. 
Penerapan Pajak Restoran di Kota Tangerang Selatan diatur dalam Peraturan Daerah No 7 Tahun 2010 sebagaimana telah diubah menjadi Peraturan Daerah Nomor 3 tahun 2017 tentang Pajak Daerah. Informan menyampaikan bahwa pajak restoran di Kota Tangerang Selatan dipungut berdasarkan pelayanan yang disediakan oleh restoran sebesar 10\%. Motif dibalik wajib pajak restoran di Tangerang Selatan seperti yang disampaikan oleh informan bahwa selama ini mereka telah menjalankan kewajibannya untuk membayar pajak restoran kepada pemerintah daerah. Pemahaman konteks dan substansi tentang apa itu pajak restoran oleh informan, berdampak kepada pemilik/pengelola restoran yang mampu menginterpretasikan pajak restoran sesuai dengan peraturan perpajakan daerah. Pemahaman tentang pajak restoran dapat membuat informan sebagai wajib pajak membantu meningkatkan penerimaan daerah lewat pajak daerah khususnya melalui pajak restoran di Kota Tangerang Selatan.

\section{Sanksi Perpajakan dan Kepatuhan Wajib Pajak Meningkatkan Realisasi Pajak Restoran}

Sejauh ini, petugas pajak daerah menjelaskan bahwa secara umum tingkat kepatuhan wajib pajak restoran di Kota Tangerang Selatan rata-rata patuh. Ungkapan pihak pajak daerah tersebut memberikan gambaran bahwa selama ini wajib pajak restoran yang terdaftar telah menjalankan kewajibannya dengan baik.

Wajib Pajak berusaha untuk selalu mengikuti peraturan daerah tentang pajak daerah dengan cara membayar pajak restoran sesuai dengan aturan pajak daerah yang berlaku. Dengan demikian, kesadaran membayar pajak dapat terlihat dari wajib pajak yang taat aturan untuk membayar pajak restoran. Timbulnya kesadaran dalam diri pengusaha/pengelola restoran untuk membayar pajak dapat meningkatkan tingkat kepatuhan wajib pajak restoran. Widodo (2010, hlm 284) menyatakan bahwa kepatuhan perpajakan sebagai suatu keadaan dimana wajib pajak memenuhi semua kewajiban perpajakan sesuai dengan peraturan yang berlaku dan melaksanakan hak perpajakannya. Dengan demikian, kepatuhan diartikan sebagai kesediaan dan kesadaran masyarakat yang telah dinyatakan sebagai wajib pajak, atau telah sesuai dengan persyaratan atas wajib pajak yang telah ditentukan berdasarkan undangundang yang berlaku dalam memenuhi kewajibannya membayar pajak.

Menurut Widodo (2010, hlm 8) faktor moralitas pajak dan budaya pajak dapat berperan dalam pembentukan kepatuhan pajak. Kepatuhan pajak dipelajari dengan cara melihat bagaimana individu membuat keputusan antara pilihan untuk melakukan kewajibannya dalam melaksanakan pajak atau justru melakukan penghindaran pajak. Budaya pajak menjadi salah satu faktor yang mampu menjelaskan kepatuhan pajak. Terdapat kecenderungan adanya peraturan atau hukum dan budaya dalam masyarakat untuk meloloskan diri dari pemenuhan kewajibannya membayar pajak, karena membayar pajak dapat dikatakan sebagai suatu aktivitas yang tidak lepas dari kondisi perilaku dan kebiasaan wajib pajak itu sendiri. Sikap taat hukum dan mengikuti peraturan pemerintah daerah yang berlaku membuat wajib pajak memutuskan untuk melakukan kewajibannya dalam melaksanakan pajak restoran, dibandingkan menghindari membayar pajak yang akan membuat wajib pajak dikenakan denda atau sanksi perpajakan yang telah ditetapkan pemerintah daerah.

\section{Menghitung Pajak Restoran Dengan Tarif Maksimal $10 \%$}

Perda Nomor 7 Tahun 2010 sebagaimana telah diubah menjadi Perda Nomor 3 Tahun 2017 tentang pajak daerah di Kota Tangerang Selatan. Salah satu jenis pajak daerah adalah pajak restoran yang diatur dalam peraturan daerah tersebut. Pajak Restoran dipungut pajak atas pelayanan yang disediakan oleh restoran. pasal 17 menjelaskan terkait obyek pajak restoran adalah pelayanan yang disediakan oleh restoran. pelayanan yang disediakan restoran meliputi pelayanan penjualan makanan atau minuman yang dikonsumsi oleh pembeli, baik dikonsumsi di tempat pelayanan maupun di tempat lain. Pasal 22 menetapkan tarif pajak restoran sebesar $10 \%$ (sepuluh persen). Besaran pokok pajak restoran yang terutang dihitung dengan cara mengalikan tarif sebagimana dimaksud dalam pasal 22 dengan dasar pengenaan pajak sebagaimana dimaksud dalam pasal 23. Cara menghitung pajak restoran yaitu:

\section{Pajak Terutang}

$=$ Tarif Pajak x Jumlah Yang Seharusnya Dibayar

$=10 \% \mathrm{x}$ Jumlah Yang Seharusnya Dibayar

Contoh pembayaran, misalnya seseorang menikmati hidangan yang disediakan oleh restoran dan melakukan pembayaran atas makanan sebesar Rp 100.000 dan minuman sebesar Rp 40.000, maka jumlah pembayaran sebesar Rp 140.000. Perhitungan pajak restoran atas transaksi tersebut, yaitu: $10 \% \mathrm{x}$ Rp $140.000=$ Rp 14.000. Pemilik/pengelola usaha restoran harus menghitung sendiri jumlah pajaknya dengan baik dan benar, serta membayarkan kepada 
bank persepsi yang telah ditunjuk, lalu melaporkannya secara tepat waktu. Karena pajak restoran menganut system self assesment. Pemungutan dalam sistem self assesment (sistem menghitung pajak sendiri) adalah suatu sistem yang pemungutan pajak yang memberikan wewenang, kepercayaan dan tanggung jawab kepada wajib pajak untuk melaksanakan sendiri kewajiban dan hak perpajakannya.

Pembayaran pajak restoran melalui bank tertentu juga disampaikan oleh pihak Bapenda Tangsel. "Wajib pajak hanya membawa kode bayar yang diperoleh dari laporan online e-SPTPD, kode bayar itu bisa langsung di transaksikan ke teller bank, bisa juga via atm”. Wajib Pajak dapat membayar pajak restoran melalui aplikasi e-SPTPD yang telah disediakan oleh pihak pajak daerah. Setelah mengisi kelengkapan data pada e-SPTPD, wajib pajak mendapatkan kode pembayaran dalam hal ini untuk membayar pajak restoran melalui bank tertentu. Wajib pajak restoran yang memenuhi kewajiban perpajakannya dengan cara menghitung, membayar dan melaporkan sendiri pajak yang terutang dengan menggunakan SPTPD (Surat Pemberitahuan Pajak Daerah). Siahaan (2016, hlm. 102) menjelaskan bahwa SPTPD adalah surat yang digunakan untuk melaporkan perhitungan dan pembayaran pajak, objek pajak atau bukan objek pajak, dan harta atau kewajiban menurut peraturan perpajakan daerah. Pajak restoran dengan menerapkan sistem self assessment ini akan berjalan dengan baik karena pemilik/pengelola restoran memiliki pengetahuan dan disiplin pajak yang tinggi dalam melaksanakan kewajiban perpajakannya secara baik dan benar.

\section{Sosialisasi Sebagai Sarana Meningkatkan Kesadaran Dan Kepatuhan Wajib Pajak Restoran}

Selain melakukan pendataan untuk setiap restoran di Kota Tangsel, pihak pajak daerah juga melakukan edukasi kepada pihak restoran terkait pajak restoran yang ada di Kota Tangsel. Bentuk sosialisasi dengan melakukan edukasi kepada pemilik/ pengelola restoran tentang kewajibannya dalam membayar pajak daerah bertujuan untuk meningkatkan kepatuhan wajib pajak dengan mentaati regulasi yang berlaku di Kota Tangerang Selatan, seperti yang diungkapkan oleh pihak bapenda "Kalau ga kita edukasi dia ga akan ini, kita sosialisasikan bahwa bapak dan ibu nih punya tempat usaha disini, ada aturannya harus mendaftarkan tempat usahanya jadi WP sesuai dengan peraturan daerah”. Sosialisasi yang dilakukan untuk menjaring usaha restoran yang masih belum terdaftar adalah sosialisasi yang dilakukan secara langsung. Yaitu, petugas pajak melakukan penyisiran secara langsung terhadap usaha restoran yang sekiranya masih belum terdaftar.

Prabhaswara (2015) menyatakan bahwa sosialisasi pajak merupakan proses pemberian informasi atau pengetahuan terkait dengan perpajakan. Sosialisasi pajak menjadi salah satu strategi penting untuk mampu memasyarakatkan pengetahuan dan peran penting pajak. Melalui penyuluhan dan sosialisasi oleh petugas pajak daerah, diharapkan dapat memudahkan masyarakat khususnya wajib pajak daerah dalam memahami perpajakan. Selain diperlukannya strategi dalam melakukan sosialisasi, sosialisasi juga bertujuan untuk meningkatkan kepatuhan maupun menjaring wajib pajak yang masih belum terdaftar. Selain itu petugas pajak juga menyampaikan bahwa sosialisasi harus dilakukan secara berulang-ulang hal ini bertujuan untuk terus meningkatkan kesadaran dan kepatuhan pajak. Kesadaran menurut Ritongga (2011) adalah perilaku atau sikap terhadap objek yang melibatkan anggapan dan perasaan serta kecenderungan untuk bertindak sebagai objek tersebut.

Hasil kegiatan sosialisasi terkait peraturan pajak restoran yang dilakukan oleh pihak Bapenda Tangsel, berdampak pada kesadaran membayar administrasi pajak dan menambah pengetahuan pajak restoran oleh wajib pajak yang masih dalam proses perizinan tempat usaha restorannya. Karena hasil yang diperoleh dari kegiatan sosialisasi tersebut dapat meningkatkan kesadaran wajib pajak restoran yang belum terdaftar dan juga dapat meningkatkan kepatuhan wajib pajak supaya sadar akan kewajibannya membayar pajak ke pemerintah daerah, sehingga pendapatan daerah dari sektor pajak daerah khususnya pajak restoran dapat terus meningkat setiap tahunnya.

Pemerintah Kota Tangsel juga melakukan sosialisasi secara langsung dengan mengundang para wajib pajak yang sudah terdaftar maupun potensi wajib pajak yang belum terdaftar. Dalam hal ini pihak bapenda menyampaikan "Selain itu juga sosialisasi kita mengundang WP yang sudah terdaftar kita kumpulkan disuatu tempat, kewajiban-kewajibannya apa saja itu kita sampaikan. Untuk undangan sosialisasi yang belum terdaftar, untuk potensi juga kita undang”. Sosialisasi perpajakan sangat dibutuhkan agar perpajakan dapat berjalan dengan baik dan lancar. Walupun banyak wajib pajak yang telah melakukan kewajiban perpajakan daerah, pemerintah dalam hal ini Bapenda Tangsel harus tetap melakukan sosialisasi. Hal ini bertujuan untuk 
membangun awareness tentang pentingnya pajak, atau dalam penelitian ini pada pajak daerah, serta menjaring wajib pajak baru, sosialisasi bagi wajib pajak baru bertujuan untuk meningkatkan pemahaman dan kepatuhan untuk memenuhi kewajiban perpajakannya.

Sosialisasi yang dilakukan oleh Bapenda dirasa masih dapat menjaring usaha restoran yang secara aturan telah memenuhi syarat menjadi wajib pajak restoran. Syarat tersebut adalah usaha restoran yang telah memperoleh omset usaha sesuai dengan peraturan pajak daerah diwajibkan untuk memotong dan membayarkan pajaknya ke pemerintah daerah. Pada saat melakukan penelitian pemilik/pengelola restoran sudah melaksanakan kewajiban membayar pajak restoran dikarenakan mereka juga sudah mendapatkan sosialisasi dari pemerintah daerah dalam hal ini petugas Bapenda Kota Tangsel.

\section{Makna Yang Timbul Dari Kesadaran Membayar Pajak Restoran}

Teori development from below memiliki pendapat bahwa orang akan lebih bersedia membayar pajak kepada pemerintah daerah dari pada kepada pemerintah pusat karena mereka dapat secara mudah melihat manfaat langsung dalam pembangunan di daerah mereka (Anggoro, 2017 hlm 322). Berdasarkan hal tersebut terlihat pentingnya pajak daerah bagi pembangunan daerah. Selain itu, manfaat dari pajak daerah dapat secara langsung dilihat dan dirasakan oleh masyarakat di daerah.

Suparnyo (2012) menjelaskan bahwa menurut teori gaya beli, fungsi pemungutan pajak dipandang sebagai gejala sosial yang dapat disamakan dengan pompa, yaitu mengambil gaya beli dari rumah tangga dalam masyarakat untuk rumah tangga negara, kemudian menyalurkannya kembali kepada masyarakat dengan maksud memelihara kehidupan masyarakat dan membawanya ke arah tertentu. Hal tersebut dapat dikaitkan dengan pajak yang dibayarkan kepada pemerintah daerah disalurkan kembali untuk kepentingan masyarakat di daerah tersebut. Pemahaman wajib pajak tentang pajak restoran berdampak pada kesadarannya untuk membayar pajak restoran, sehingga berpengaruh pada peningkatan penerimaan pajak restoran. Makna yang timbul dari wajib pajak restoran memenuhi kewajiban perpajakannya sebagai berikut:

\section{Membayar Pajak Sebagai Bentuk Timbal} Balik Kepada Pemerintah Daerah

Membayar pajak restoran menjadi suatu kewajiban yang harus dilakukan sebagai pemilik/ pengelola restoran yang menggunakan fasilitas milik pemerintah, hal tersebut diungkapkan oleh salah satu informan bahwa "Pajak di restoran itu adalah sesuatu yang wajib bagi setiap pemilik restoran untuk dibayarkan ke pemerintah, karena kita ini kan memakai tanah pemerintah iya kan, yaa jalan depan itu kan jalan pemerintah, ya sudah sewajibnya pemerintah mendapatkan fee”. Manfaat Pajak restoran yang dibayarkan dirasakan sebagai salah satu bentuk bantuan pemerintah daerah untuk membantu kelangsungan usaha restoran dalam menjalankan kegiatan operasional sehari-hari.

Makna pajak restoran sebagai bentuk timbal balik kepada pemerintah daerah dialami oleh informan. Kemudahan konsumen untuk mengakses jalan menuju tempat usahanya dirasakan sebagai bentuk timbal balik pemerintah daerah membantu memperoleh pendapatan usaha lewat pajak restoran yang dibayarkan oleh wajib pajak. Manfaat pajak restoran yang semakin dirasakan oleh informan akan berdampak pada peningkatan kemauan wajib pajak restoran membayar pajak kepada pemerintah daerah. Hal inilah dimaksudkan dengan pemungutan pajak untuk kepentingan yang dipungut atau pihak yang membayar pajak. Manfaat pajak restoran ini mempengaruhi naik turunnya kemauan wajib pajak restoran membayar pajak.

\section{Ketenangan Berbisnis Dengan Menyetorkan \\ Pajak Restoran}

Dimensi lain makna pajak restoran diakui oleh informan sebagai ketenangan dalam memperoleh penghasilan dari bisnis usaha restoran, disaat peneliti bertanya tentang pajak restoran yang dibayarkan oleh informan menuturkan bahwa "Yaa kalo buat saya sih ya bagus kan karena disini juga tempat harus dibayar gitu kan, jadi kita wajar buat ngasih ke pihak pajaknya”. Perspektif yang sama diungkapkan oleh informan lain sebagai wajib pajak restoran bahwa membayar pajak dapat menghindari usaha restoranya dari denda apabila tidak membayar pajak "Kalo itu kan kita harus taat hukum ya, kalo saya sih kalo kita tidak bayar pajak itu endingnya nanti kita akan dikenakan denda oleh pemerintah iya kan, jadi kita mengikuti apa namanya peraturan pemerintah yang dibuat”. Kepatuhan membayar pajak restoran menurut informan disebabkan oleh kesadarannya terhadap hukum atau peraturan daerah yang mengatur tentang pajak restoran. Peraturan tersebut yang membuat pihak restoran harus membayar pajak restoran supaya menjadi wajib pajak yang taat terhadap hukum/peraturan yang berlaku, dan menghindari denda yang akan diberikan pihak pajak daerah apabila tidak patuh membayar pajak restoran. 
Dengan demikian, apabila restorannya mengikuti aturan hukum untuk membayar pajak, restorannya akan aman dari sanksi pihak pajak daerah jika menghindari pajak. Secara tidak langsung yang ia rasakan adalah ketenangan dalam memperoleh penghasilan dari bisnis usaha restorannya. Ketenangan melakukan bisnis dirasakannya saat usaha restoran selalu mengikuti peraturan pemerintah daerah.

\section{Membayar Pajak Berarti Berkontribusi Untuk Daerah}

Moralitas pajak dapat didefinisikan sebagai motivasi yang muncul dalam diri individu untuk membayar pajak (Widodo, 2010 hlm. 9). Motivasi tersebut dapat muncul dari kewajiban moral atau keyakinan untuk berkontribusi kepada negara atau dalam hal pajak daerah dapat berkontribusi untuk daerahnya sendiri dengan membayar pajak. Pajak restoran diungkapkan informan sebagai kewajiban restoran yang bertujuan untuk pembangunan daerah, "Kalau yang saya liat sih kadang juga ada yang tidak bayar pajak tapi kalau menurut saya sih wajib kalo bayar pajak gitu, bisa untuk pembangunan daerah juga seperti jalan raya”. Pihak Bapenda Tangsel juga mengungkapkan hal serupa terkait pajak yang digunakan untuk membangun daerahnya sendiri, "Ya untuk daerah kan dikembalikan lagi, pajak itu adalah peran serta masyarakat dan wajib sebenernya hukumnya wajib dan sifatnya memaksa kalau kamu tidak sanggup bagaimana lagi karna ini sudah kewajiban kamu sebagai warga negara untuk membayar pajak dan itu ikut membangun daerahnya”.

Makna pajak restoran diungkapkan oleh informan sebagai kontribusi kepada pemerintah daerah untuk dapat melaksanakan pembangunan daerahnya sendiri. Prakoso Anggoro (2017), menjelaskan dua faktor yang mempengaruhi pelaksanaan pemungutan pajak sehingga wajib pajak bersedia ikut berkontribusi kepada pemerintah daerah. Pertama, Tingkat kemampuan dan ketersediaan tenaga trampil di daerah yang dibutuhkan sebagai tenaga pelaksana administrasi perpajakan di daerah. Kedua, Sejauh mana kedekatan pemungut pajak dengan wajib pajak daerah

Wajib pajak restoran yang mampu menginterpretasikan pajak restoran sebagai tanggung jawab perpajakannya, maka wajib pajak tersebut telah membantu pemerintah daerah ikut berkontribusi untuk membangun daerahnya sendiri. Kedekatan emosional yang telah dibangun oleh pihak pajak daerah dengan wajib pajak daerah dalam hal ini wajib pajak restoran, berdampak positif dalam hal peningkatan kepatuhan wajib pajak itu sendiri untuk ikut berkontribusi kepada pemerintah daerah.

\section{Kesadaran Membayar Pajak Membentuk \\ Rasa Tanggung Jawab Sosia}

Jaya (2016) menjelaskan bahwa peningkatan kesadaran masyarakat dalam memenuhi kewajiban perpajakannya dapat dibentuk dengan memberikan penyuluhan kepada wajib pajak bahwa pajak tersebut sangat penting bagi penerimaan pendapatan daerah demi menunjang kesejahteraan masyarakat sehingga dapat terbentuknya pemahaman dari masyarakat tentang hak dan kewajiban yang dimilikinya sesuai dengan peraturan perundang-undangan perpajakan yang berlaku. Jika kesadaran wajib pajak meningkat maka kepatuhan wajib pajak akan meningkat. Tingkat kepatuhan pelaporan pajak akan lebih tinggi ketika wajib pajak memiliki tanggung jawab moral yang lebih kuat (Jaya, 2016).

Makna pajak sebagai sarana tanggung jawab sosial dirasakan oleh beberapa informan sebagai wajib pajak restoran di Kota Tangsel. Informan mengungkapkan manfaat pajak restoran yang telah ia bayarkan "Untuk masyarakat juga, buat kita bersama gitu, kalau yang saya liat sih kadang juga ada yang tidak bayar pajak, tapi kalau menurut saya sih wajib kalo bayar pajak, kegunaannya ya buat kita juga sih kita kan bayar terus buat kita juga sebenernya, dari rakyat untuk rakyat juga kalau menurut saya”. Menurut Informan membayar pajak restoran sebagai bentuk kewajiban yang tidak boleh dilanggar karena nantinya pajak tersebut dapat digunakan pemerintah daerah untuk pembangunan daerah, karena pajak restoran yang dibayarkan adalah untuk kepentingan bersama, berasal dari masyarakat daerah Tangsel dan akan dinikmati kembali oleh masyarakat di daerah Tangsel. Widodo (2010, hlm. 17) menjelaskan bahwa moralitas pajak dapat diukur melalui sikap dan pendirian individu dalam melaksanakan kewajiban perpajakannya. Hal tersebut dapat dlihat sebagai kewajiban moral individu yang membayar pajak, keyakinan untuk berkontribusi kepada masyarakat dengan membayar pajak.

Pajak restoran yang dibayarkan dianggap sebagai tanggung jawab sosial dalam membayar pajak restoran dipahami oleh informan yaitu "Kalo pastinya pendapat saya, kalo pajak ini kan untuk kebaikan kembali untuk warga kita sendiri untuk jalan bisa, mungkin ada dana bantuan panti asuhan atau banyaklah hal-hal positif yang harus disalurkan, jangan hal-hal yang negatif. Saya harap pajak yang didapat pemerintah digunakan untuk hal-hal positif 
yang bisa membantu warga khususnya warga Tangsel sendiri”. Menurutnya, pajak restoran yang ia bayar merupakan bentuk lain dari kepeduliannya terhadap kehidupan sosial dan ikut berpartisipasi dalam mewujudkan tanggung jawab dan nilai-nilai sosial kemasyarakatan.

Hasil dari pajak menurutnya dapat digunakan untuk kegiatan sosial yang positif seperti membangun fasilitas untuk warga Tangsel yang membutuhkan bantuan. Selain itu, pajak restoran sebagai bentuk kepercayaan kepada pemerintah daerah untuk membantu mewujudkan kemakmuran dan kesejahteraan masyarakat daerah Tangsel. Penyelenggaraan pajak untuk kepentingan masyarakat inilah yang dapat dianggap sebagai dasar keadilan pemungutan pajak, bukan kepentingan individu dan juga bukan kepentingan pemerintah daerah, melainkan untuk kepentingan masyarakat yang meliputi kedua-duanya, yaitu pembayar pajak dan pemerintah daerah.

Pajak restoran menjadi salah satu bagian penerimaan daerah dari sektor perpajakan daerah. Pajak restoran yang dapat diterima dengan baik oleh wajib pajak dimana mereka telah memahami terkait besarnya tarif pajak restoran, siapa yang harus membayar pajak tersebut, dan sanksi terhadap pelanggaran pajak. Sehingga akan timbul dalam diri masyarakat atau wajib pajak itu sendiri rasa patuh atau ketaatan untuk membayar pajak. Kepatuhan wajib pajak yang timbul dalam dirinya sendiri akan berdampak positif untuk meningkatkan penerimaan daerah dari sektor pajak dan membantu kemajuan daerahnya itu sendiri.

\section{SIMPULAN DAN SARAN}

\section{Simpulan}

Penelitian ini berjudul makna pajak restoran dalam perspektif wajib pajak restoran bertujuan untuk mengetahui bagaimana wajib pajak restoran dalam hal ini pemilik/pengelola usaha restoran di Kota Tangerang Selatan memaknai pajak restoran yang menjadi kewajiban perpajakan daerah. Pembahasan ini telah dilakukan menggunakan pendekatan fenomenologi dalam penelitian kualitatif dan paradigma interpretif. Kesimpulan yang diperoleh dari penelitian ini adalah sebagai berikut:

a. Penelitian ini mendeskripsikan bahwa pemilik/ pengelola usaha restoran di Kota Tangerang Selatan memahami tentang substansi pajak restoran. Mereka memahami bahwa pajak restoran adalah sebuah kewajiban sebagai warga negara yang mendirikan usaha restoran disuatu daerah terhadap pemerintah daerah yang dapat dijadikan sebagai salah satu sumber penerimaan daerah untuk membiayai keperluan pemerintah daerah.

b. Substansi pajak restoran juga dipahami oleh mereka sebagai sesuatu yang mempunyai relevansi dengan hubungan timbal balik kepada pemerintah daerah. Pemahaman ini disebabkan karena apa yang mereka bayar berupa pajak restoran berdampak positif terhadap usaha mereka sehingga secara konkrit mereka memahami substansi pajak restoran sebagai bentuk balas jasa kepada pemerintah daerah.

c. Penelitian ini menemukan bahwa selain sebuah kewajiban sebagai warga negara yang menjalankan usaha disuatu daerah. Sebagai wajib pajak restoran juga memahami pajak restoran sebagai bentuk ketenangan dalam berbisnis, ketenangan dalam menjalankan usaha restoran ia dapatkan setelah memenuhi kewajibannya sebagai wajib pajak daerah dan tidak berupaya untuk menghindari perpajakan daerah.

d. Makna lain dari pajak restoran dipahaminya sebagai bentuk kontribusi kepada pemerintah daerah. Motivasi yang timbul dari wajib pajak untuk ikut berperan meningkatkan penerimaan daerah, didasari oleh kewajiban moral atau keyakinan wajib pajak itu sendiri untuk berkontribusi kepada negara atau dalam hal ini membayar pajak daerah dapat berkontribusi untuk daerahnya sendiri dengan membayar pajak restoran.

e. Dimensi lain dari pajak restoran bagi wajib pajak restoran di Kota Tangerang Selatan adalah sebagai wujud tanggung jawab sosial. Manusia adalah makhluk sosial yang tidak dapat hidup sendiri tanpa bantuan orang lain. Oleh karenanya pajak restoran yang dibayar oleh pihak restoran dianggap sebagai wujud tanggung jawab sosial terhadap masyarakat dan lingkungannya, menurutnya pajak restoran yang mereka bayar nantinya akan kembali ke masyarakat juga. Saran

Berdasarkan hasil yang ada di dalam penelitian ini, maka bagi penelitian selanjutnya dapat menambahkan sampel wajib pajak restoran melebihi penelitian ini. Penelitian selanjutnya juga dapat mengembangkan fenomena yang ada dari sudut pandang pendekatan lainnya, seperti metode etnometodologi, etnografi, ataupun studi kasus. Sehingga mampu memperluas hasil penelitian yang ada ke arah yang lebih baik lagi. 


\section{DAFTAR PUSTAKA}

Peraturan Daerah Kota Tangerang Selatan Nomor 3 Tahun 2017 tentang Perubahan Peraturan Daerah Kota Tangerang Selatan Nomor 7 Tahun 2010 tentang Pajak Daerah.

, Peraturan Daerah Kota Tangerang Selatan Nomor 7 Tahun 2010 tentang Pajak Daerah.

Undang-Undang Nomor 28 Tahun 2009 tentang Pajak Daerah dan Retribusi Daerah.

Anggoro, D.D. 2017. Pajak Daerah dan Retribusi Daerah. Malang: UB Press.

Anggraini, R.Y. 2017. Masuknya Paradigma Interpretif pada Kajian Ilmu Akuntansi. Jurnal Analisa Akuntansi dan Perpajakan, Volume 1, Nomor 1, hlm. 51-62.

Cresswell, John W. 2018. Penelitian Kualitatif \& Desain Riset: Memilih diantara Lima Pendekatan” Edisi ke3 (Ahmad Lintang Lazuaradi, dkk, Penerjemah), Yogyakarta: Pustaka Pelajar.

Darmayasa, I.N., Yuyung, R.A. 2015. Paradigma Interpretif Pada Penelitian Akuntansi. Indonesia. Jurnal Akuntansi Multiparadigma. Volume. 6 Nomor. 3, hlm. 341-511. ISSN 2086-7603.

Hasbiansyah. 2008. Pendekatan Fenomenologi: Pengantar Praktik Penelitian dalam Ilmu Sosial dan Komunikasi. Mediator Vol.9 No.1 Juni 2008. SK No.56/DIKTI/Kep/2005.
Jaya, I.B.M., Jati, I.K. 2016. Pengaruh Kesadaran, Kualitas Pelayanan, Pemeriksaan dan Sanksi Perpajakan pada Kepatuhan Wajib Pajak Restoran. E-Jurnal Akuntansi Universitas Udayana, Volume 16.1, hlm. 471-500, ISSN: 2302-8556

Moleong, J.L. 2017. Metodologi Penelitian Kualitatif, Edisi Revisi, (Anggota Ikapi, Penerjemah), Bandung: PT Remaja Rosdakarya.

Prabhaswara, S. 2015. Penerapan sosialisasi pajak daerah atas rumah kost di Kota Depok. Perbanas Review, Vol. 1, No. 1

Raco, J.R. 2010. Metode Penelitian Kualitatif: Jenis, Karakteristik, dan Keunggulannya. Jakarta: PT Grasindo.

Ritonga, P. 2011. Analisis Pengaruh Kesadaran dan Kepatuhan Wajib Pajak Terhadap Kinerja Kantor Pelayanan Pajak (KPP) dengan Pelayanan Wajib Pajak Sebagai Variabel Intervening di KPP Medan Timur. Universitas Islam Sumatera, Medan.

Sarnia. 2015. Polisemi Dalam Bahasa Muna. Jurnal Humanika. No. 15, Vol. 3, ISSN: 1979-8296.

Suparnyo. 2012. Hukum Pajak Suatu Sketsa Asas. Semarang: Pustaka Magister Semarang.

Siahaan, M.P. (2016). Pajak Daerah dan Retribusi Daerah. Jakarta: Rajawali Pers.

Widodo, W., dkk. 2010. Moralitas, Budaya dan Kepatuhan Pajak. Bandung: Alfabeta. 